it appears only in the second state of the engraving and cannot be attributed to the artist himself, ${ }^{28}$ the inscription is nevertheless curiously appropriate, for facing the viewer in the center foreground is a teetering skater on the point of falling. Furthermore, the inscription can be related to a number of sixteenth-century proverbial expressions in which cracking ice or simply skating were metaphors for danger or going wrong, in much the same way as "skating on thin ice" is today. Cracked ice was "evil" ice (Cract ijs, quaet ijs) in the sixteenth century, and "I stand on cracking ice" (Ic sta op crakende ijs) was said when things were going wrong. However, merely to lead or bring someone onto the ice (Jemand opt ijs leyen or opt den ijs brenghen) meant placing him in a dangerous position and "to go on skates" (Op schaatsen gaan) meant to go astray. ${ }^{29}$

The delight that Bruegel took in illustrating the pithy wisdom embodied in such sayings is well known, but proverbs are not the only possible source for the motif. As was the case with the bird trap, the same ideas may equally be found in the emblematic tradition, where the deceptive solidity of ice had inspired several reflections on the instability of human affairs. An emblem of a man breaking through the ice published by Théodore de Bèze in 1580 represents, according to the epigram, the uncertainty of life; ${ }^{30}$ and Joachim Camerarius (the Younger) used the image of a fox who listens for the unseen but dangerous water running beneath the ice to illustrate prudent foresight. ${ }^{31}$ Consequently, when in 1635 George Wither wrote the epigram for an emblem of a man walking on ice which contains the following lines, he was merely repeating what was, evidently, a widespread conceit during the sixteenth and seventeenth centuries:

We are all Travellers; and all of us

Have many passages, as dangerous,

As Frozen-lakes; and Slippery-wayes, we tread,

In which our lives may soon be forfeited,

(With all our hopes for Life-eternall, too)

Unlesse, we well consider what we doe. ${ }^{32}$

In Bruegel's painting, bird catching and life on the ice as allegorical themes have been completely subsumed under the natural appearance of the everyday world. Yet for its contemporary

${ }^{28}$ But see now the interpretation of A. Monballieu, "P. Bruegels 'Schaatsenrijden bij de St.-Jorispoort te Antwerpen,' de betekenis van het jaartal 1553 en een archiefstuck," Jaarboek van het Koninklijk Museum voor schone Kunsten Antwerpen, 1981, 17-29, which relates the inscription and Bruegel's drawing to a construction scandal in Antwerp.

${ }^{29}$ These proverbial expressions have been adduced by Dirk Bax, Ontciffering van Jeroen Bosch. The Hague, 1949, 12 (for which see now the English translation, Hieronymus Bosch: His Picture Writing Deciphered, Rotterdam, 1979), to explain the strange hybrid creature on skates in the left wing of Bosch's Temptation of Saint Anthony Triptych (Lisbon, Museu Nacional de Arte Antigua). The little figures skating or bound to enormous skates hurtling headlong through the broken ice in the fieryfrozen Hell of the Garden of Earthly Delights Triptych (Madrid, Prado) seem to exploit the same repertoire.

${ }^{30}$ Icones, Geneva, 1580, No. 19. Reproduced in Henkel and Schöne (as in note 14), col. 111.

31 Symbolorum et Emblematum, Nuremberg, 1595, II, No. 55. Similar emblems appear in Jacobus à Bruck (called Angermundt), Emblemata Moralia \& Bellica. Cologne, 1615, No. b 13, and in Jacob Cats, Emblemata Moralia et Aeconomica, Rotterdam, 1627, No. 15. For all of these, see Henkel and Schöne, col. 457.

${ }^{32}$ A Collection of Emblems (London, 1635), ed. John Horden, Mewston, Yorkshire, 1968, 153. viewer, the picture would surely have illustrated them and therefore served as a warning that man's condition is a precarious one, that evil temptations surround him, and that only the prudent and conscientious can hope to achieve eternal life. Thus the two halves of the painting - of the skaters and the bird trap - would have formed a complementary unity of content that is as persuasive as is the formal impression of a winter's day.

University of California Irvine, CA 92717

\section{The Chronology of the De Monte Chapel in S. Pietro in Montorio in Rome}

\section{Alessandro Nova}

The documentation of the De Monte Chapel is vast: so many letters, descriptions, documents, and drawings relate to the chapel that it could stand alone as a suitable subject for a long and detailed analysis. ${ }^{1}$ The purpose of this article is to investigate the written sources in order to understand how a prestigious commission of this kind was handled by the artists, how they were paid, and the nature of their collaboration. A few documents are unpublished. Some were referred to by Karl Frey, but he did not specify where he had found them, and three rather important ones regarding Giorgio Vasari and Bartolomeo Ammannati were unknown to him.

Cardinal Antonio De Monte, uncle and mentor of Giovanni Maria (the future Pope Julius III), had been closely connected with the English monarchy and more directly with Cardinal Bainbridge. As a result of this relation, in $\mathbf{1 5 2 9}$ he declared his wish to be buried beside Bainbridge in St. Thomas of Canterbury in Rome. ${ }^{2}$ After Henry VIII's defection, however, Antonio's will transferred this wish to S. Pietro in Montorio, where he was buried upon his death in September, 1533. ${ }^{3}$

1 The most recent and valuable investigations on the chapel are those by J. Pope-Hennessy, 60 and Cat. No. 75, and by C. Davis, 476 and $480-$ 84. The latter briefly returned to the problem in "The Tomb of Mario Nari for the SS. Annunziata in Florence," Mitteilungen des Kunsthistorischen Institutes in Florenz, xxI, 1977, 69-94 (esp. 82). These scholarly enquiries suggested an interesting direction to pursue, to which I here wish to contribute with a full analysis of the documents. For the drawings connected with the Chapel, see P. Barocchi, Mostra dei disegni del Vasari e della sua cerchia. Florence, 1964, 23, No. 15, fig. 9; C. Monbeig-Goguel, Vasari et son temps. Inventaire général des dessins italiens. Musée du Louvre, Paris, 1972, 154-56, Nos. 200-02; E.P. Pillsbury, review of C. Monbeig-Goguel, 1972, in Master Drawings, xI, 1973, 173, pl. 34; C. Davis, review of L. Vagnetti, ed., 2000 anni di Vitruvio and L. Vagnetti, Prospettiva ..., in Journal of the Society of Architectural Historians, xxxix, 1980,252 , fig. 1. Each of these authors published different drawings related to the project. See also C. Davis's entry in the exhibition catalogue Giorgio Vasari-Principi, letterati e artisti nelle carte di Giorgio Vasari, Florence, 1981, 93-94.

2 See T. Falk, "Studien zur Topographie und Geschichte der Villa Giulia in Rome," Römische Jahrbuch für Kunstgeschichte, xIII, 1971, 104. On the relationship between Bainbridge and Antonio De Monte, see D.S. Chambers, Cardinal Bainbridge in the Court of Rome, 1509-1514, London, 1963.

${ }^{3}$ Copia de una letera: mandata: $A$ vno Pricipe de Italia de li funerali particulari del Reuerendissimo Cardinal de Mōte, n.p., 1533, unpaginated: "asanto Pietro in montorio locho di monte \& distante da la sua Casa vn' miglio o circa, Doue per testamento se hauea epso Disposto" (page 5 , according to my own pagination). A copy is in the Vatican Library, Chigi Iv 2204 int. 12. 
As soon as he was elected Pope (February 7-8, 1550), Julius III decided to commission from Vasari a prestigious funerary monument for his uncle. This was immediately expanded into a project for a family chapel to be built beside the altar of S. Pietro in Montorio. Vasari informs us that the commission occurred after the coronation (February 22, 1550) and after the Pope had rested for a certain time (quietato alquanto) ${ }^{4}$; in a letter addressed to Vasari from Florence, Cosimo Bartoli congratulated the artist on having obtained the commission: since this letter is dated April 5 , and implies a letter received from Rome, the plan must have been agreed upon in March. ${ }^{5}$ This information is relevant since we know the exact date of the contract; June $2,1550.6$ This means that there was a gap of about two and a half months between the commission (that is, the general agreement) and the specific contract. This interval was dedicated to drawings, contacts, and agreements with other artists who were to be involved in the enterprise. Michelangelo fixed the price and attended assiduously to the commission. ${ }^{7}$ The choice of the sculptor fell on Bartolomeo Ammannati, who was entrusted with the work before May 28, $1550 .^{8}$

The original contract is interesting because it is detailed and based on a wooden model. From it we learn that:

Vasari was the only artist responsible for the commission. The statement "Iulio III ... conviene ... con meco che io pigli a fare et far condurre" makes clear that Vasari was the artistic entrepreneur for this enterprise. Michelangelo is recorded as supervisor; he was not paid since he already received a monthly salary of fifty scudi from the Pope. Ammannati was commissioned to carve only two of the four statues. This means that Michelangelo and the Pope were not disposed to grant him unlimited trust. Bartolomeo's skill, however, won Michelangelo over, who a year later described the young sculptor as "l'angelo Bartolomeo," comparing Ammannati with himself by referring to what contemporaries called him: Michel Angelo. As at the Villa Giulia, therefore, Ammannati's initial role was limited to that of assistant to Vasari, even if he was working independently. Later he was

\footnotetext{
4 Vasari, vil, 693.

5 For Bartoli's letter, see Frey, 281, letter cxxxvil, April 5, 1550.

- G. Vasari, Il libro delle ricordanze, ed. A. Del Vita, Arezzo, 1927. 66-67.

7 Vasari himself informs us that Michelangelo fixed the price (G. Vasari, vir, 226). For Michelangelo's rejection of Vasari's first projects, and of the proposal for collaboration by Simone Mosca and Raffaello da Montelupo, see Vasari, vi, 308, and vir, 226-27.

${ }^{8}$ Frey, 288, letter cxL (V. Borghini to G. Vasari), May 28, 1550. C. Davis, $1976,480-83$, has pointed out that according to Cosimo Bartoli's Ragionamenti accademici, it was Michelangelo who chose Vasari and Ammannati. But even if Michelangelo supervised the commission, it is not clear whether he chose either of the artists. In the case of Vasari it is well known, first, that Michelangelo esteemed him more as an architect than as a painter; and, second, Vasari had already worked for Julius III when the latter was still a cardinal, since the artist had planned De Monte's villa at Monte Sansavino (Frey, 225, letter cxIv) (which indicates, incidentally, at Monte Sansavino (Frey, 225, letter Cxiv) (which indicates, incidentally, that the project for the Chapel was not Vasari's first architectural work); third, there was a very good reason why the Pope should entrust Vasari directly with this project: the artist was a distant relative. Andrea, an aunt of Julius III, had married Giovanni Desiderio Tullonense; their daughter Elisabetta married Giovanni Bacci of Arezzo (see A. Fortunio, Cronichetta del Monte San Savino di Toscana, Florence, 1583, 41). Nicolosa Bacci was Vasari's wife. It now becomes clear why Giovanni Maria De Monte was so interested in persuading the artist to marry (VaMari 690). In a letter addressed to Vasari, C. Bartoli wrote: "seruendo un papa et poi parente, so, che stillerete piu di 7 uolte il cervello in $\mathrm{m}$ -
}

entrusted with all the sculptures, including the balustrade, and also shared responsibility for the enterprise with Vasari. ${ }^{10}$

All the elements recorded - comprising the marble coat-ofarms, which is over the entrance to the chapel, flanked by the four Evangelists, and putti holding festoons, the frescoes and stucchi of the vault, the four Church Fathers and the two stucco coatsof-arms on the pilasters flanking the chapel, and the altarpiece were executed in accordance with the contract.

The specifications as to materials (such as the ultramarine blue for the altarpiece and the Carrara marble) were also respected, as was the scheduled time for completion of the work: in fact, the chapel was finished two months in advance. Vasari's contract allowed for completion within thirty months, that is, by the end of 1552, but in a letter of October 22, 1552, Vincenzo Borghini already knew that the chapel had been finished. Frey thought that Borghini was alluding to the paintings, but this is improbable since the letter seems to refer to the chapel as a whole. Borghini writes: "L'honoratissimo messer Michelagnolo uostro son certo che fara ufitio di buono amico et dintendente artefice et di huomo ueramente da bene."11 This refers to the fact that Michelangelo, having fixed the price for the chapel, was now to give his approval of the work done, and consequently of the payment to Vasari: for this to be done the whole chapel must have been near completion, since Vasari was responsible for the ensemble. Moreover, a document (see below Doc. No. 12) records that the marble balustrade was by then (October, 1552) already underway. It is, however, possible that one or two statues were executed later.

As to iconography, the three stucco Prophets at the top of the vault and the four Virtues framing the storie of Saint Paul were not mentioned in the contract. This suggests that agreement on materials and other formal aspects was regarded as of greater significance than agreement on iconography. The Prophets and Virtues were, however, minor iconographic details, which could have been added later.

The cost of the chapel was astonishing: more than 3,700 gold scudi (Balduino De Monte, the Pope's brother, paid 5,500 scudi

uenzioni" (Frey, 281).

In the case of Ammannati: first, according to the contract, he was to carve only two of the four main statues; this clause would seem rather cautious if Ammannati had been directly chosen by Michelangelo; second, he could easily have been recommended by one of his powerful protectors, such as Archbishop Antonio Altoviti, son of Bindo (a papal banker), or the Paduan professor of law, Marco Mantova Benavides, who dedicated his Enchiridion, published in 1551, to Julius III (see Davis, 479). The relationships between the Pope and his artists were unstable and intricate. The project was initially assigned to Vasari under Michelangelo's supervision; the latter rejected Vasari's first plans and possibly intervened in the design of the Chapel, as suggested by J. Pope-Hennessy, 60; Ammannati's role, however, increased in importance during the construction phase, and he probably introduced some variations under Michelangelo's approval.

9 Barocchi-Ristori, 366 (August 22, 1551).

10 Ammannati's role has been discussed in detail by J. Pope-Hennessy, 1970, cat., p. 76, and by Davis, who wrote: "The parallels between the design of the del Nero tomb and that of the del Monte monuments in S. Pietro in Montorio perhaps indicate that Ammannati had a larger share in the planning of the latter than is often suggested" (Davis, 484). In this article, Davis investigated with great care the commission of Francesco del Nero's tomb in which Michelangelo acted as arbiter between the patron and Ammannati. As suggested by Davis, it was probably commissioned earlier than the De Monte Chapel, but Michelangelo's involvement dates only from 1558 .

11 Frey, 337-38, letter CLXXv. 
for the entire Palazzo Branconio Dell' Aquila). ${ }^{12}$ Vasari was to receive an advance of 1,000 scudi for the first six months, followed by four instalments of 675 scudi every six months. A total of 3,400 scudi was for materials (but not for masonry); the remaining 300 scudi were Vasari's fee. Since the masonry cost 618.98 scudi (see below Doc. No. 5), the total sum spent on the chapel was 4,318 scudi and 98 baiocchi. ${ }^{13}$

The interest of the subsequent documents in relation to the contract lies in the fact that they show how the stages of the operation were subdivided.

Early in June, 1550, Vasari and Ammannati left Rome and went to Carrara where the latter negotiated contracts for the marble. ${ }^{14}$ In Rome, work on the masonry had not yet started, since in late July/early August the Pope was considering moving the family chapel to S. Giovanni dei Fiorentini. ${ }^{15}$ Ammannati's return to Rome in early October must have precipitated a decision: both the marble and the artist were in the city, and Julius III finally settled on S. Pietro in Montorio. On October 13, 1550, Michelangelo informed Vasari of the Pope's wish: ${ }^{16}$ more than four months had elapsed from the date of the contract, but immediately after the letter was sent, the masons began their work.

The first payments are to the master mason, Giacomo Varesio: (1) "Addi da di 18. di ottobre fino addi 8. di Nouemb. in 3. partite $\Delta$ Cento sesanta à m. ${ }^{\text {ro }}$ Giac. ${ }^{\circ}$ mur. ${ }^{\text {re }}$ à buon conto della sepoltura del R. ${ }^{\text {mo }}$ Car. ${ }^{\text {al }}$ de Monti bo: me. che N.S. ${ }^{\text {re }}$ ha fatto principiare in S. Pietro Montorio

$\Delta$ 160" (A.S.R. Camerale I, Fabbriche, Busta 1517B. Unpublished; referred to by Frey, 295). Michelangelo's letter and this document together show that the work was started between October 13 and 18, 1550. Since Vasari returned to Rome only towards the end of December, ${ }^{17}$ Ammannati must have been entrusted with its supervision.

According to A.S.R. - Camerale I, Fabbriche, Busta 1517B the master mason Giacomo Varesio was paid again on: (2) November 29, 155018; (3) January 9, 1551; (4) February, 1551; (5) March 2, 1551.

The last payment (referred to by Frey, 295) tells us that the total sum for the masonry was 618 scudi and 98 baiocchi; the estimate for this work had been calculated three months previously (December 8, 1550).

12 The editions of the Ricordi by Del Vita (Arezzo, 1927, 67) and Frey $(1930,869)$ both transcribe an error found in the manuscript, according to which the total sum was 4,700 scudi. The text of the contract, however, makes clear that the sum was 4,070 scudi: "scudi di giulj numero quatro mila settanta." They are scudi di moneta. Since ten gold scudi were equivalent to eleven scudi di moneta, 3,700 gold scudi were equivalent to 4,070 scudi di moneta. For the Palazzo Branconio Dell' Aquila, see C.L. Frommel, Der Römische Palastbau der Hochrenaissance, Tübingen, 1973, II, 15, Doc. 15.

13 Frey records payments for masonry on August 2, 1551, for the considerable sum of 122 scudi and 94 baiocchi (Frey, 295). I could not find this document. If Frey is correct, the total sum for the chapel was 4,441 scudi and 92 baiocchi.

${ }^{14}$ See G. Campori, Memorie biografiche degli scultori, architetti, pittori nativi di Carrara e di altri luoghi della provincia di Massa .... Modena, 1873, 263-4; and Vasari, vi, 98.

15 Barocchi-Ristori, 346 (August 1, 1550).

16 Ibid., 355

17 Frey, 294.

18 Published by A. Bertolotti, Artisti lombardi a Roma nei secoli XV, XVI, e XVII. Studi e ricerche negli archivi romani, Milan, 1881, I, 58.

19 Daniele da Volterra received a first payment for the Sala della Cleopatra
From this document we learn that less than two months (October $13 / 18$ - December 8 ) were required for the construction of a chapel of remarkable dimensions; the workers (and the artists) were paid retroactively. This was almost always the rule. When discussing payments, one must take into account that they were frequently settled days, months, sometimes even years late (as, for example, Daniele da Volterra was for the Sala della Cleopatra, or Ammannati was for the Villa Giulia). ${ }^{19}$

Eleven days after the completion of the masons' work, an artisan was paid for the golden nails for the new coffin of Cardinal Antonio: (6) "Addi 19. di $\mathrm{X}^{\mathrm{m}}$ bre $\Delta$ otto à $\mathrm{m}$. ${ }^{\text {ro }}$ Andrea per prezzo di tanti chiodi dorati per la cassa della sepol. ${ }^{\text {ra }}$ di S. Pietro Montorio del Car. al bo: me: de Monti" (A.S.R. - Camerale I, Tesoreria Segreta, Busta 1295A. Unpublished).

Although, according to the contract, Vasari was promised an advance payment, he did not receive it for nine months; it was eventually paid on February 25,1551 : (7) "Addi 25 detto $\Delta$ mille di oro à Giogino pittoŕ à buon conto della pittura della cappella di S. Pietro Montorio $\Delta 1100^{\prime \prime}$ (A.S.R. - Camerale I, Fabbriche, Busta 1517B. Unpublished). Frey, referring to the "Ricordo of 25th February 1551," stated that the painting of the chapel commenced that very day. ${ }^{20}$ This is incorrect. First, there is no such Ricordo; secondly, even if Frey was referring to the above document, the scaffolding was built only in August. Such an enormous payment cannot refer to the altarpiece. The 1,000 gold scudi are obviously the first instalment of the contract. This is interesting since it raises the question of whether Vasari (and Ammannati on his behalf) advanced the money for the marble purchased in Carrara, or whether the artisans there were paid in arrears.

It is likely that Vasari started working on the altarpiece after receiving this payment, but the frescoes were not begun before late summer/early autumn, 1551. In the meantime a chain (for the vault or the gate of the chapel) was ordered: (8) "Addi detto [May 22, 1551] $\Delta$ Trenta à Franco chiauari per costo di un migliaro et mezo di ferro dato a Pellegrino fabro per far la cathena à S. Pietro Montorio $\Delta 30^{\prime \prime}$ (A.S.R. - Camerale I, Tesoreria Segreta, Busta 1295B. Unpublished). Vasari received a further payment in June: (9) "Agiorgio pittore abuonconto della

on October 18, 1550 (see J.S. Ackerman, The Cortile del Belvedere; Vatican City, 1954, 164, Doc. 70a). Curtio Macherone was paid for his work on the Cleopatra fountain (placed in the same room) in April, 1551 (Ackerman, 165, Doc. 75), which seems to suggest that by then the frescoes were for the most part completed. The account with Daniele da Volterra, however, was settled only four years later; the last payment, dated March 22, 1555 (Ackerman, 165, Doc. 79), was the credit due to Daniele for his work in the Sala della Cleopatra. The fact that Julius III had fallen terminally ill a few days previously suggests that payment was made only because of the administration's desire to settle the Pope's accounts before his death (March 23, 1555) (see the numerous letters sent by Annibale Caro to Cardinal Alessandro Farnese regarding the Pope's final illness published in A. Ronchini, Lettere d'uomini illustri conservate in Parma nel $R$. Archivio dello Stato, Parma, 1853, 414-24). Ammannati received no official payment but only some gifts for his architectural and sculptural works at the Villa Giulia. As late as 1570 , fifteen years after Julius Ill's death, Ammannati prepared an official claim for the thirty-four months that he had worked for the De Monte. This account was submitted to Cosimo I, who had inherited part of the De Monte's properties after the family's extinction (see L. Biagi, "Di Bartolommeo Ammannati e di alcune sue opere," L'arte, xxvi, 1923, 49-66; and C. Davis, "Four Documents for the Villa Giulia," Römisches Jahrbuch für Kunstgeschichte, xvII, 1978, 219-226).

20 Frey, 294. 


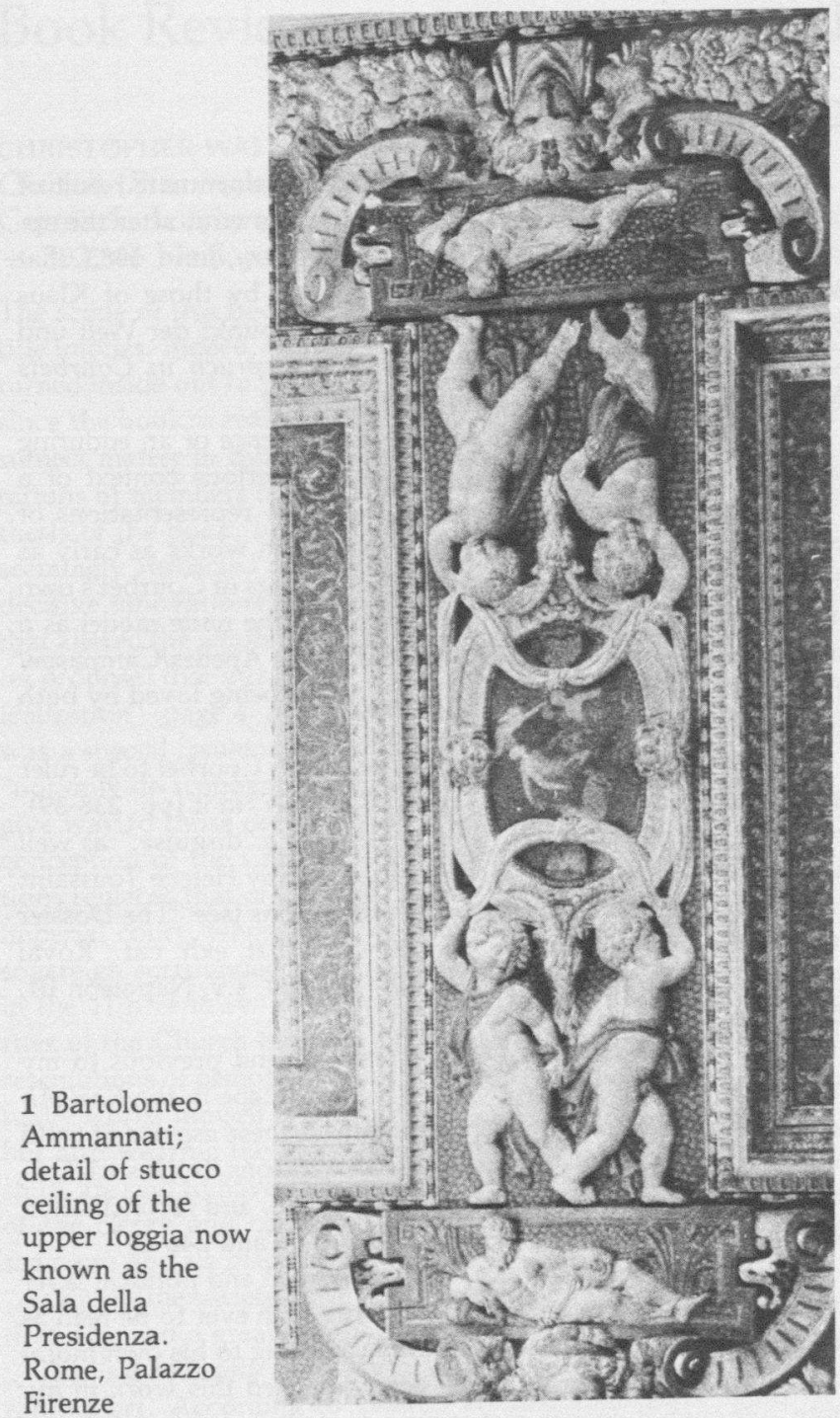

pittura della cappella di sanpietro amontori della buona $\mathrm{M}$ del $\mathrm{R}^{\mathrm{mo}}$ uecchio cento sessantacinque addi 5 digiugno [1551] pagho detto $\Delta 165^{\prime \prime}$ A.S.R. - Camerale I, Appendice, Busta 92 , fol. 67v. Unpublished). This document is probably related to another unpublished payment to Ammannati. Vasari left Rome early in July, 1551. ${ }^{21}$ (Was the altarpiece finished?) On the tenth, Ammannati was paid 500 gold scudi. The total of the two sums is 665 scudi. There are no longer four regular instalments of 675 scudi, but apparently similar amounts of money received

\footnotetext{
22 Ibid., 390.

22 "Al palazo di campo marzo tutto quello che vi si spese che fu vicino a 20 milia ducati adetto palazo loggedistuco palchi faccate rifatte einsomma quello che ve dinnouo fu disegniato dame" (A.S.F. - Compagnie religiose soppresse da P. Leopoldo-139, filza 1036, fol. 106r).

${ }^{23}$ For Gamucci's sentence, see B. Gamucci, Libri quattro dell' antichità della città di Roma, Venice, 1565, 175. The stucchi have usually been ascribed to Giulio Mazzoni (see, for example, A. Pettorelli, Giulio Mazzoni da Piacenza pittore e scultore, 1921, 16). This attribution probably arose because the opposite and identical Ricci Chapel was executed by Mazzoni in the 1560's after the death of his master Daniele da Volterra: Mazzon was a gifted and well-known stuccatore. Moreover, he worked in Vasari's orkshop, but the biographer himself informs us that Mazzoni learned
}

at irregular periods. Furthermore, Ammannati was paid for painting, sculpture, and altri lavori, the latter providing a base for attributing the stuccoes to him. The putti of the vault are indeed almost identical to those of the magnificent ceiling (Fig. 1) of the upper loggia (now known as the Sala della Presidenza) in the Palazzo Firenze in Rome (at that time owned by the De Monte family). Ammannati himself wrote that he had been the only architect responsible for the embellishment of the Palazzo Firenze, including its stucco loggias and ceilings. ${ }^{22}$ The attribution of the Chapel's stuccoes to Ammannati is confirmed by the sculptor's friend Bernardo Gamucci, who recorded not only the statues and the balustrade as by Bartolomeo, but also "l'opera delli stucchi, che dal medesimo con bell' arte ui furon fatti." 23 The fact that Ammannati was paid for painting, sculpture, and altri lavori shows that he was no longer working under Vasari, but probably as his associate. He received the payment because Giorgio had left Rome: (10) "Addi $x$ di luglio [1551] $\Delta$ Cinquecento di oro in. ${ }^{\circ}$ à $\mathrm{m}$. ${ }^{\text {ro }}$ Bart. ${ }^{\circ}$ scultore fior. ${ }^{\text {no }}$ à buon conto della pittura et scultura et altri lauori per la cappella et fab. ${ }^{\text {ca }}$ della sepoltura di S. Pietro Montorio $\Delta 550^{\prime \prime}$ (A.S.R. - Camerale I, Fabbriche, Busta 1517B. Unpublished).

In August Michelangelo informed Vasari that the sculptor was working very well, ${ }^{24}$ and in the same month the scaffolding was built: (11) "Addi 30 di Agosto [1551] $\Delta$ quarantacinque b 90: à $\mathrm{m}$. ${ }^{\text {ro }} \mathrm{Giac}{ }^{\circ}$ muratore per costo di tanti legnami ch' hà dati à fare li ponti per li pittori alla cappella della bo: me. del Car. ${ }^{\text {al }}$ di Monte di S.P.ro montorio $\Delta 45: 90^{\prime \prime}$ (A.S.R. - Camerale I, Fabbriche, Busta 1517B. Unpublished; referred to by Frey, 294). The scaffolding was erected during Vasari's absence from Rome. The words "li pittori" indicate that the paintings had been entrusted to Vasari's assistants (probably Gherardi and Veltroni). Giorgio returned in October, $1551^{25}$ - did they start without him, following his drawings? Vasari spent most of 1552 in Rome, where he and his assistants completed the frescoes, probably during the first months of the year: the date painted on the exterior of the chapel is MDLII.

The sculpture was almost completed by October, 1552 . On the third, Vasari was paid for the marble balustrade on which Ammannati was working: (12) "Addi 3: di Ottobre [1552] $\Delta$ cento doro per poliza del S. ${ }^{\mathrm{r}}$ Thes. ${ }^{\mathrm{r}}$ di N.S. ${ }^{\mathrm{r}}$ a m Giorgio Vassari pittore à buon conto del parapeto che fa alla cappella di S. Pietro Mont. ${ }^{\circ}$ di marmo $\Delta 110^{\prime \prime}$ (A.S.R. - Camerale I, Fabbriche, Busta 1519; referred to by Frey, 292).26

In a letter dated October 22, 1552, Borghini already knew that the chapel was finished: ${ }^{27}$ "Ho grandissimo piacere, che lopera uostra sia finita." It is, however, possible that some of the statues (the two personifications?) had not yet been executed. Frey published a document recording the balance of a payment due to Ammannati (July, 1554). ${ }^{28}$ This is recorded as the last payment

to make works in stucco from Daniele (Vasari, vII, 70). Cardinal Ricci, who had been a faithful collaborator of Julius III, simply asked Mazzoni to copy the stuccoes designed and partly executed by Ammannati for the De Monte Chapel.

${ }^{24}$ Barocchi-Ristori, 366.

${ }^{25}$ Frey, 390.

26 The document was published by A. Gabrielli, "Su Bartolommeo Ammannati," La critica d'arte, II, fasciolo 2, 1937, 92, n. 13, with some inaccuracies.

27 Frey, 337-38.

${ }^{28} \mathrm{~K}$. Frey, "Studien zu Michelagniolo Buonarroti und zur Kunst seiner Zeit," Jahrbuch der Königlichen Preuszischen Kunstsammlungen, Beiheft zum XXX, 1909, 163, Doc. 333. 
for the chapel and refers to a mandato dated September 11, 1553. As we have seen, artists were frequently paid retroactively. It is therefore also possible that Ammannati finished his work by December, 1552, as required by the contract, but that he received the mandato (recording only 23 scudi and 20 baiocchi as the balance of the previous payment) in September, 1553, and was finally paid in July, 1554. Julius III's negligence in paying his employees strengthens this possibility. After only a few months of the pontificate, Vasari, who was at that time the Pope's favorite artist, commented to Francesco Buonanni: "Certo tanto raro è [Cosimo I] fra questi principi, che si dilettano piu (di adoperarci) che di rumunerarci." 29

University of Milan Milan, Italy

\section{Bibliography}

A.S.F.: Archivio di Stato, Florence.

A.S.R.: Archivio di Stato, Rome.

Barocchi, P., and R. Ristori, Il Carteggio di Michelangelo, iv, Florence, 1980.

Davis, C., "Ammannati, Michelangelo, and the Tomb of Francesco del Nero," Burlington Magazine, cxvin, 1976, 472-84.

Frey, K., Der literarische Nachlass Giorgio Vasaris, 1, Munich, 1923; II, Munich, 1930.

Pope-Hennessy, J., Italian High Renaissance and Baroque Sculpture, 2nd rev. ed., London, 1970.

Vasari, G., Le vite de' più eccellenti pittori scultori ed architettori, ed. G. Milanesi, Florence, 1878-1885.

\section{Letter}

\section{Courbet's Real Allegory}

I write to express my regret that, as the unfortunate result of lack of access and availability, I was unaware until after the appearance of my note on Courbet's Real Allegory, June, 1983, that several of the conclusions were anticipated by those of Klaus Herding in "Das Atelier des Malers - Treffpunkt der Welt und Ort der Versohnung," Realismus als Widerspruch in Courbets Malerei, Frankfurt, Suhrkamp, 1978, 223-247.

In this work, Herding establishes the existence of an enduring tradition in which the puzzle-like and mysterious context of a "real allegory" may be seen as analogous to representations of penetrable disguises, representations found in works as early as 17th-century Enigmata as well as in the writings of Courbet's own immediate circle (pp. 224-25). He also sees the nude model as a muse (pp. 243 and 314, n. 88), related to the Apelles/Campaspe/ Alexander myth (pp. 231 and 311, n. 45) in being loved by both painter and monarch.

Herding treats the entire painting, and finds Courbet to be ruler and judge over the whole assembly of "equals" in it (pp. 238-39), one of whom is Napoleon III. The Emperor's "disguise," as well as those of others on the left, was penetrated by Helene Toussaint to reveal portraits of both persons and nations (see "The Dossier of 'The Studio' by Courbet," Gustave Courbet, exh. cat., Royal Academy of the Arts, London, 1978, 249-280, s.v. Napoleon III, 265-266).

More specifically, even more important, and previous to my publication, Klaus Herding viewed the landscape in the Real Allegory as free and true. He further connects these aspects of truth and freedom with sought-for outward extensions to the social order where all can find regeneration, salvation, and reconciliation in the promise of a better future (pp. 240-41 and 246-47).

Herding has here analyzed a complex social and political layer of meaning, which permits Courbet more than ever to be read as a "modern" artist who uses tradition according to his own moral convictions. I regret not having acknowledged this work in my note, although it does in fact serve a context somewhat different from the one I attempted to treat.

At the same time, I am happy to discover that the pictorial emblems that I was able to present, in order to demonstrate the persistence of visual tradition in Courbet's painting, can serve not only to confirm and corroborate the earlier interpretations of the work, but Klaus Herding's as well, which I gladly credit.

MARGARET ARMBRUST SEIBERT Columbus College of Art and Design Columbus, $\mathrm{OH} 43215$ 